\title{
LOWER WEIGHT GAIN AFTER VAPING CESSATION THAN AFTER SMOKING QUITTING*
}

\author{
Ewelina Wawryk-Gawda', Michat K. Zarobkiewicz' ${ }^{2}$ Patrycja Chylińska-Wrzos ${ }^{1}$, Barbara Jodłowska-Jędrych ${ }^{1}$
}

\author{
${ }^{1}$ Chair and Department of Histology and Embryology with Experimental Cytology Unit, \\ Medical University in Lublin, Poland \\ ${ }^{2}$ Department of Clinical Immunology, Medical University in Lublin, Poland
}

\begin{abstract}
Background. Smoking is frequently a way to control appetite and weight. The data concerning the body mass gain after quitting among the users of electronic cigarettes who have no prior history of smoking traditional cigarettes is inconsistent. Objective. In our study we have compared smoking and vaping impact on weight gain and glycaemia.

Material and methods. 3 groups of rats were used. The group A was exposed to vapour and group B were exposed to smoke. Rats in the group $\mathrm{C}$ constituted the control group without nicotine exposition.

Results. During 6 weeks of experiment weight gain of rats in the A and B groups was comparable, while animals from group $\mathrm{C}$ had gained signifi0cantly more. During 2 weeks after cessation of exposition to nicotine animals from group B gained more weight than rats of A and C group. Blood glucose was higher in group B than in groups A and C $24 \mathrm{~h}$ after last exposure to nicotine and 2 weeks after nicotine exposure cessation.

Conclusion. Effects of vaping on weight increase is similar to smoking, but after vaping cassation weight gain is lower and comparable with nicotine nonusers.
\end{abstract}

Key words: nicotine, cigarettes, weight, smoking, vaping, electronic cigarettes

\section{STRESZCZENIE}

Wprowadzenie. Palenie papierosów jest często stosowaną metodą utrzymywania niskiej masy ciała i kontroli apetytu. Badania dotyczące przyrostu masy ciała wśród osób, które nigdy nie paliły tradycyjnych papierosów i zaprzestały stosowania papierosów elektronicznych są niejednoznaczne.

Cel badań. W naszym badaniu porównaliśmy wpływ papierosów tradycyjnych i elektronicznych na przyrost masy ciała i poziom cukru we krwi.

Materiał i metody. Do badania użyto 3 grupy szczurów. Grupa A była eksponowana na parę z podgrzania płynu papierosa elektronicznego, grupa B została poddana działaniu dymu tytoniowego. Zwierzęta grupy C stanowiły grupę kontrolną bez narażenia na nikotynę.

Wyniki. W trakcie 6 tygodni trwania eksperymentu przyrost masy ciała szczurów z grupy A i B był porównywalny, natomiast zwierzęta $\mathrm{z}$ grupy $\mathrm{C}$ przybrały istotnie więcej. Podczas 2 tygodni następujących po zaprzestaniu ekspozycji zwierzęta z grupy B przybrały więcej niż szczury z grypy A i C. Glikemia była najwyższa w grupie B zarówno bezpośrednio po zakończeniu ekspozycji, jak i po 2 tygodniowej przerwie w narażeniu na nikotynę.

Wnioski. Wpływ stosowania papierosów elektronicznych na przyrost masy ciała jest porównywalny do palenia papierosów tradycyjnych w trakcie ekspozycji. Natomiast po zakończeniu narażenia na pary liquidu przyrost masy ciała jest mniejszy, podobnie jak w grupie kontrolnej.

Slowa kluczowe: nikotyna, papierosy, masa ciała, palenie, papierosy elektroniczne.

\section{INTRODUCTION}

The maintenance of the correct body mass is one of the most important factors determining the health and well-being of people. Currently, obesity constitutes a major civilization problem and leads to the development of numerous diseases [16]. The studies conducted among smokers, and female

Corresponding author: Ewelina Wawryk-Gawda, Katedra i Zakład Histologii i Embriologii z Pracownią Cytologii Doświadczalnej, Uniwersytet Medyczny w Lublinie, ul. Radziwiłłowska 11, 20-080 Lublin, tel. +48 508191144, e-mail: ewelina.wawryk-gawda@umlub.pl

*The study is the part of grant of Minister of Science and Higher Education No MNmb 246.

(C) Copyright by the National Institute of Public Health - National Institute of Hygiene 
smokers in particular, indicate that one of the main factors deciding whether to start and continue smoking is the decrease in body weight caused by smoking [3, $7,19,23]$. Smoking is frequently a way to control appetite and weight [7]. The results of many studies confirm that smokers weigh on average 4-5 $\mathrm{kg}$ less than non-smokers and quitting smoking leads to evening of these discrepancies [3, 6, 28]. The increase in body weight after smoking cessation is connected mainly with the increased food intake, metabolic changes including energy expenditure as well as eating sweets to minimalize the symptoms of nicotine withdrawal $[26,28]$. Supplements containing nicotine belong to the products easing the quitting of smoking. Nevertheless, their effectiveness in reduction of weight gain after smoking cessation is not clear [1,23]. One of the methods enhancing smoking cessation is the use of electronic cigarettes $[14,23,26]$. Inhalation of aerosol from vaporized liquid (vaping) containing nicotine is used as treatment of smoking dependence and they may be useful to those smokers who also suffer from the obstructive pulmonary diseases or cancers $[8,11$, $18,19,20,23]$.

The gain of body weight after quitting the traditional cigarettes (t-cig) smoking in electronic cigarettes users (e-cig) is smaller than in non-users [23]. What is more, the data concerning the body mass gain after quitting among the smokers of electronic cigarettes who have no prior history of smoking traditional cigarettes is inconsistent. Currently, the usage of e-cigarettes does not concern only those in the in the quitting process. E-cigarettes are becoming a substance popular among adults and youth who have no prior history of any kind of nicotine intake [7, 13, 22]. Many young people from different social backgrounds use e-cigarettes in particular in the situation when they have perceived themselves as overweight [7, 29]. Exclusive vaping without smoking is still a short term phenomenon and that is why no consistent conclusions can be drawn concerning the impact of e-cigarette usage over the period of many years upon living organisms [10].

In our study, we have compared smoking and vaping impact on weight gain and glycaemia. Additionally, we have studied if the cessation of smoking or vaping can lead to the increase of weight and decrease of glycaemia.

\section{MATERIALS AND METHODS}

Our experiment was conducted on 30 male Wistar rats. The animals were divided into three groups: A, $\mathrm{B}, \mathrm{C}$. The animals in the group A have been exposed to vapour of scent free liquid with total nicotine dose of $7 \mathrm{mg}$ per 24 hours. During the 10 minute exposition the rats were placed in a PCV cage of the $0.1 \mathrm{~m}^{3}$ volume and they were given the inhalation of $0.6 \mathrm{ml}$ liquid (propylene glycol, water, nicotine) by using suction and pressure device. The rats in the group B were exposed to smoke from 10 traditional cigarettes total nicotine dose of $7 \mathrm{mg}$ per 24 hours. The exposition was conducted 5 days a week over the period of 6 weeks. In total, each experimental group was given $210 \mathrm{mg}$ of nicotine. The rats in the group $\mathrm{C}$ constituted the control group and they were exposed to the same inhalation-related stress that other rats but without the nicotine element. The animals were weighed twice every 2 weeks. Each rat was placed in the metabolic cage over the period of 24 hours 6 weeks and 8 weeks after the experiment has begun. The water intake and urine excretion as well as the weight of the food consumed and faecal matter excreted and the number of debris were measured. Measurements of blood glucose in rats were done with glucometer 6 weeks and 8 weeks after the beginning of the experiment. Normal glycaemia have been previously established at $117.06 \pm 1.96 \mathrm{mg} / \mathrm{d}$ [5]. All work was conducted with the formal approval of the local animal care committees (30/2015).

\section{RESULTS}

\section{Body weight gain during experiment.}

Mean weight of rats at the beginning of experiment starts was $187.82 \pm 12.56 \mathrm{~g}$. During first 6 weeks of experiment animals of the group A (e-cig) gained $55.93 \%$, group B (t-cig): 57.54 and group C: $66.86 \%$ (Figure 1 and 2). 2 weeks after cessation of exposition to smoke and vapour the animals of group A gained $9.73 \%$, group B: $13.20 \%$, group C: $7.20 \%$ (Figure 3).

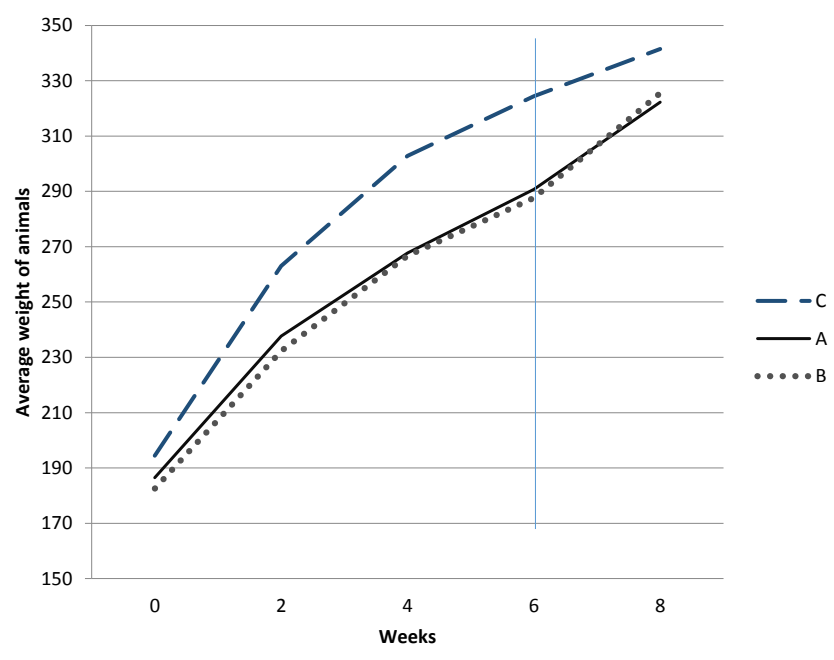

Figure 1. Changes of weight during experiment in each group (C: control, A: e-cig ,B: t-cig).

C- control group, A: e-cigarettes group, B: traditional cigarettes group 


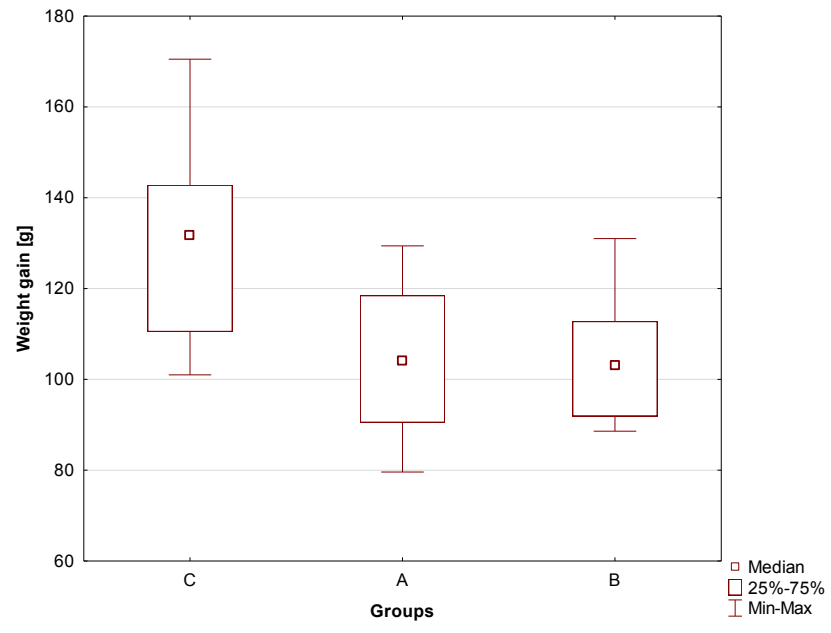

Figure 2. Weight gain after 6 weeks of electronic cigarettes (A) and traditional cigarettes (B) exposition. The U Mann Whithney's Test A:C p=0.01, B:C p=0.01, $\mathrm{A}: \mathrm{B} \mathrm{p}=0.96$.

\section{Metabolic parameters of rats}

The amount of the consumed food and water intake and the volume of urine and faeces excreted

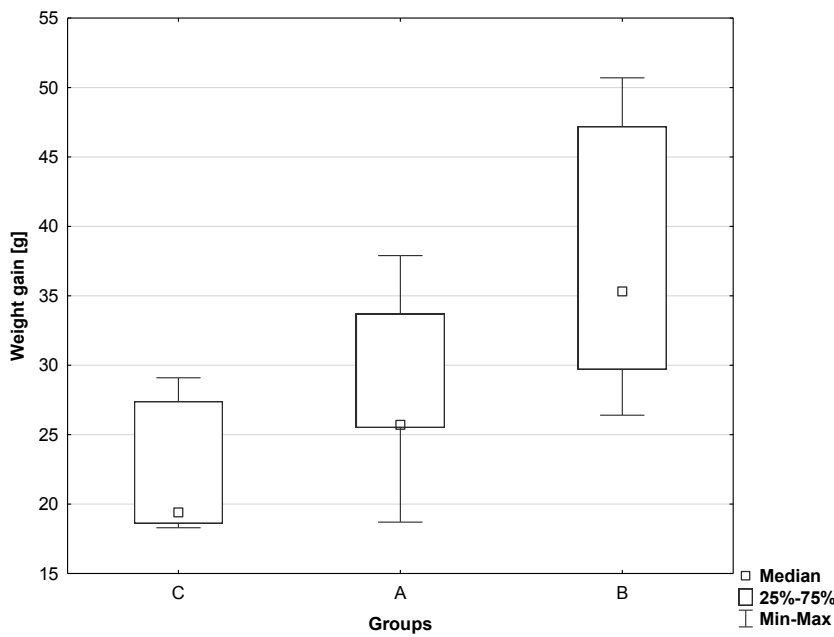

Figure 3. Weight gain after 2 weeks post nicotine exposure cessation. The U Mann Whithney's Test $\mathrm{P}$ value $\mathrm{A}: \mathrm{C} \mathrm{p}=0.29, \mathrm{~B}: \mathrm{C} \mathrm{p}=0.04, \mathrm{~A}: \mathrm{B} \mathrm{p}=0.14$.

insignificantly varied during groups both while nicotine exposition (Table 1) and after the nicotine exposure cessation (data not included).

Table 1. Metabolic parameters measured in the metabolic cages. The difference in the water and food intake and the volume of excreted urine and faeces were not statistically relevant

\begin{tabular}{|c|c|c|c|c|}
\hline $\begin{array}{l}\text { Measured } \\
\text { parameter }\end{array}$ & A & B & $\mathrm{C}$ & $p$ value in the $U$ test \\
\hline water $[\mathrm{ml}] \pm \mathrm{SD}$ & $24.00 \pm 1.41$ & $30.00 \pm 5.00$ & $27.50 \pm 3.54$ & $\begin{array}{l}A: C p=0.44 \\
B: C p=0.77 \\
A: B p=0.25\end{array}$ \\
\hline urine $[\mathrm{ml}] \pm \mathrm{SD}$ & $10.50 \pm 0.71$ & $11.00 \pm 1.00$ & $10.75 \pm 1.06$ & $\begin{array}{l}A: C p=0.67 \\
B: C p=0.80 \\
A: B p=0.77\end{array}$ \\
\hline $\begin{array}{l}\text { food [g] } \\
\pm \text { SD }\end{array}$ & $19.05 \pm 0.49$ & $21.63 \pm 2.01$ & $21.5 \pm 0.99$ & $\begin{array}{l}A: C p=0.25 \\
B: C p=0.77 \\
A: B p=0.56\end{array}$ \\
\hline $\begin{array}{c}\text { faeces [g] } \\
\quad \pm \mathrm{SD}\end{array}$ & $6.65 \pm 0.35$ & $6.40 \pm 1.42$ & $9.65 \pm 0.78$ & $\begin{array}{l}A: C p=0.25 \\
B: C p=0.15 \\
A: B p=0.80\end{array}$ \\
\hline
\end{tabular}

Blood glucose was higher in group $\mathrm{B}$ than in groups $\mathrm{A}$ and $\mathrm{C} 24 \mathrm{~h}$ after last exposure to nicotine and after 2 weeks after the nicotine exposure cessation.

in group $\mathrm{C}$, but after 2 weeks without e-cig exposure blood glucose was at the same level that in the control In group A glycaemia was insignificantly higher than group (Table 2).

Table 2. Glycaemia after exposition for electronic (A) and traditional (B) cigarettes

\begin{tabular}{|c|c|c|c|c|}
\hline Glycaemia $\quad$ Group & A & B & $\mathrm{C}$ & $\begin{array}{l}\mathrm{p} \text { value in the } \\
\mathrm{U} \text { test }\end{array}$ \\
\hline $\begin{array}{c}\text { after } 6 \text { weeks of nicotine exposure } \\
\qquad \mathrm{SD}\end{array}$ & $\begin{array}{c}139.40 \pm 5.74 \\
\mathrm{mg} / \mathrm{dl}\end{array}$ & $\begin{array}{c}160.00 \pm 9.22 \\
\mathrm{mg} / \mathrm{dl}\end{array}$ & $\begin{array}{c}123.40 \pm 4.56 \\
\mathrm{mg} / \mathrm{dl}\end{array}$ & $\begin{array}{l}A: C p=0.14 \\
B: C p=0.01 \\
A: B p=0.04\end{array}$ \\
\hline $\begin{array}{c}\text { after } 2 \text { weeks of exposure cessation } \\
\pm \mathrm{SD}\end{array}$ & $\begin{array}{c}129.40 \pm 4.39 \\
\mathrm{mg} / \mathrm{dl}\end{array}$ & $\begin{array}{c}152.00 \pm 8.89 \\
\mathrm{mg} / \mathrm{dl}\end{array}$ & $\begin{array}{c}121.8 \pm 18.32 \\
\mathrm{mg} / \mathrm{dl}\end{array}$ & $\begin{array}{l}A: C p=0.35 \\
B: C p=0.03 \\
A: B p=0.01\end{array}$ \\
\hline
\end{tabular}




\section{DISCUSSION}

The mechanism through which smoking decreases body weight gain is complex [3]. Nicotine as a sympathomimetic agent, is responsible for the decrease of appetite, raising the resting metabolic rate and lipolysis. Catecholamine production, increased by nicotine, may limit the body weight gain even without the decrease in food intake $[3,15$, 25]. Sympathomimetic drugs increase the energy expenditure by effecting the peripheral tissue and through regulation of metabolism in the brain. Nicotine promotes the local release of norepinephrine within body tissues and systemic release of epinephrine from the adrenal glands $[3,24]$.

In our study we have observed similar body weight gain in the group exposed to traditional and electronic cigarettes and higher in the control group, although the intake of water and food was similar. The decrease in the body weight without decreased appetite has been observed before by Schechter et al. in rats that received nicotine intraperitoneally [25]. On the other hand, El Golli et al. [9] have shown a significant decrease in food and energy intake after nicotine or e-liquid were given intraperitoneally. In that study, rats treated with nicotine and e-cigarette have had lower body weight gain $(41.9 \pm 4.6 \mathrm{~g}$ and $45.7 \pm 2.1 \mathrm{~g}$, respectively) than rats from the control group $(53.6 \pm 4.6 \mathrm{~g})$. On the contrary, Ponzoni et al. have observed similar weight in mice exposed to e-cig vapour and the mice from the control group, but mice exposed to conventional cigarettes had lower weight [21]. Studies conducted among young people have indicated that higher weight is associated with higher frequency of e-cigarette using, but probably they were more motivated to decrease their weight by vaping than slim people [4].

Smoking causes likewise hyperglycemia by activation of glycogenolysis and gluconeogenesis in hepatocytes [24]. These processes leading to release of free glucose into bloodstream, may be activated by high concentration of circulating epinephrine and norepinephrine due to smoking even without hypoglycemia [24]. Insulin resistance and increased percentage of visceral fat that enhances the risk of diabetes mellitus and atherosclerotic cardiovascular disease have also been described as the effect of nicotine administration $[3,28]$. Moreover, it has been observed that smoking increases blood glucose level and can subsequently cause diabetes. The increased glucose level makes it more difficult to quit smoking and increases the pathological metabolic changes. Thus, high level of blood glucose not only constricts smoking or vaping quitting but also enhances the rewarding effects of nicotine that have been observed in diabetic rats [12].
In our study we observed the highest level of glycaemia in the group exposed to traditional cigarettes and just slight increase in the group exposed to electronic cigarettes. After cessation of the exposure to traditional cigarettes, rapid increase in body weight was observed, while in the groups exposed to e-cig weight gain was lower, comparable to the control group. Similarly, blood glucose was similarly higher both before and after quitting smoking in rats from group B when compared to the group A before or after vaping ceased.

Lower cytotoxicity of vapour exposition to vapour have been observed in certain studies. Smoking traditional cigarettes induces oxidative stress and increases reactive oxygen species (ROS) and pro-inflammatory cytokines production $[17,28]$. ROS damage organs and induce apoptosis of cells of pancreatic islets which lead to the decrease of insulin production and diabetes mellitus development [24]. However, only high dose of vapour seem capable of inducing reactive oxygen species, causing DNA damage, and reducing cell viability [2]. In the study of Mathew et al., aerosol of e-cig liquid have induced production of pro-inflammatory cytokines in the airway epithelium [17]. In contrary, electronic cigarette aerosol have neither activated the oxidant-stress sensing transcription factor NFR2 (nuclear factor, erythroid 2-like 2, NFE2L2,) nor up-regulated cytochrome 450 or cellular biomarkers of biologically relevant levels of free radicals in human coronary artery endothelial cells [27].

Conventional cigarettes seem more harmful than electronic cigarettes due to the tar substances present in the smoke $[2,6,17]$. More studies are needed to explain the differences observed in the effects of conventional and electronic cigarettes.

\section{CONCLUSIONS}

Electronic cigarettes may be a healthier alternative to traditional cigarettes for people addicted to nicotine at least in terms of weight gain. Effects of vaping on weight increase is similar to smoking, but after vaping cassation weight gain is lower and comparable with nicotine nonusers. Therefore, it may be useful to switch to e-cigarettes prior to complete quitting at least for individuals afraid of weight gain.

\section{Acknowledgments}

The study was founded by the grant of the Polish Minister of Science and Higher Education No MNmb 246.

\section{Conflicts of interest}

The authors declare no conflict of interest.

\section{Ethical approval}

All work was conducted with the formal approval of the local animal care committees (30/2015). 


\section{REFERENCES}

1. Allen A.M., Kleppinger A., Lando H., Oncken C.: Effect of nicotine patch on energy intake and weight gain in postmenopausal women during smoking cessation. Eat Behav. 2013;14(4):420-3.

2. Anderson C., Majeste A., Hanus J., Wang S.: E-Cigarette Aerosol Exposure Induces Reactive Oxygen Species, DNA Damage, and Cell Death in Vascular Endothelial Cells. Toxicol Sci. 2016;154(2):332-40.

3. Audrain-McGovern J., Benowitz N.L.: Cigarette smoking, nicotine, and body weight. Clin Pharmacol Ther. 2011;90(1):164-8.

4. Bennett B.L., Pokhrel P.: Weight Concerns and Use of Cigarettes and E-Cigarettes among Young Adults. Int J Environ Res Public Health 2018; 15(6):1084.

5. Brăslaşu E.D., Brădăłan C., Cornilă M., Cojmăleałă R., Brăslaşu M.C.: Normal blood glucose in white wistar rat and its changes following anesthesia. Lucrări Ştiintifice Medicină Veterinară 2007;4: 120-123.

6. Chatkin R., Chatkin J.M.: Smoking and changes in body weight: can physiopathology and genetics explain this association? J Bras Pneumol. 2007;33(6):712-9.

7. Cho B.Y., Seo D.C., Lin H.C., Lohrmann D.K., Chomistek A.K., Hendricks P.S., Timsina L.: Adolescent Weight and Electronic Vapor Product Use: Comparing BMI-Based With Perceived Weight Status. Am J Prev Med. 2018;55(4):541-50.

8. Dautzenberg B., Garelik D.: Patients with lung cancer: Are electronic cigarettes harmful or useful? Lung Cancer 2017;105:42-8.

9. El Golli N., Dkhili H., Dallagi Y., Rahali D., Lasram M., Bini-Dhouib I., Lebret M., Rosa J.P., El Fazaa S., AllalEl Asmi M.: Comparison between electronic cigarette refill liquid and nicotine on metabolic parameters in rats. Life Sci 2016;1,146:131-8.

10. Fearon I.M., Eldridge A.C., Gale N., McEwan M., Stiles M.F., Round E.K.: Nicotine pharmacokinetics of electronic cigarettes: A review of the literature. Regul Toxicol Pharmacol 2018;100:25-34.

11. George O., Grieder T.E., Cole M., Koob G.F.: Exposure to chronic intermittent nicotine vapor induces nicotine dependence. Pharmacology Biochemistry and Behavior 2010;1,96(1):104-7.

12. Íbias J., O’Dell L.E., Nazarian A.: Insulin dependent and independent normalization of blood glucose levels reduces the enhanced rewarding effects of nicotine in a rodent model of diabetes. Behav Brain Res 2018; 01,351:75-82.

13. Jongenelis M.I., Brennan E., Slevin T., Kameron C., Rudaizky D., Pettigrew S.: Differences in use of electronic nicotine delivery systems by smoking status and demographic characteristics among Australian young adults. Health Promot J Austr 2018;6; doi: 10.1002/hpja.202. [Epub ahead of print].

14. Kim B., Yoo S., Cho S.I.: Association between stages of change for smoking cessation and electronic cigarette use among adult smokers: A nationwide cross-sectional study in Korea. PLoS ONE. 2018;13(9):e0204244.
15. Liu M., Chuang Key C.C., Weckerle A., Boudyguina E., Sawyer J.K., Gebre A.K., Spoo W., Makwana O., Parks J.S.: Feeding of tobacco blend or nicotine induced weight loss associated with decreased adipocyte size and increased physical activity in male mice. Food Chem Toxicol. 2018 Mar;113:287-95.

16. Martin K.A., Mani M.V., Mani A.: New targets to treat obesity and the metabolic syndrome. Eur J Pharmacol. 2015;15,763:64-74.

17. Mathew D., Hwang J.H., Crotty Alexander L.E.: Electronic Cigarette Inhalation Promotes Inflammatory Cytokines Within the Airways and Systemic Inflammation in Mice. Am J Respir Crit Care Med 2016;193:A4844

18. Melin K., Conte-Schmidt N., Martínez-Arroyo K., Rosa-Pérez K., Soto-Avilés A.E., Hernández-Muñoz J.J.: Knowledge and Perceptions of E-cigarettes and the Motivations for their Use: Talking to Smokers (E-cigarettes and/or Conventional Cigarettes) and Non-smokers in Puerto Rico. P R Health Sci J 2018;37(3):148-54.

19. Morean M.E., Wedel A.V.: Vaping to lose weight: Predictors of adult e-cigarette use for weight loss or control. Addict Behav. 2017;66:55-9.

20. Polosa R., Morjaria J.B., Prosperini U., Russo C., Pennisi A., Puleo R., Caruso M., Caponnetto P.: Health effects in COPD smokers who switch to electronic cigarettes: a retrospective-prospective 3-year follow-up. Int J Chron Obstruct Pulmon Dis. 2018; 22, 13:2533-42.

21. Ponzoni L., Moretti M., Sala M., Fasoli F., Mucchietto V., Lucini V., Cannazza G., Gallesi G., Castellana C.N., Clementi F., Zoli M., Gotti C., Braida D.: Different physiological and behavioural effects of e-cigarette vapour and cigarette smoke in mice. Eur Neuropsychopharmacol. 2015;25(10):1775-86.

22. Rohde J.A., Noar S.M., Horvitz C., Lazard A.J., Cornacchione Ross J., Sutfin E.L.: The Role of Knowledge and Risk Beliefs in Adolescent E-Cigarette Use: A Pilot Study. Int J Environ Res Public Health 2018; 23,15(4).

23. Russo C., Cibella F., Mondati E., Caponnetto P., Frazzetto E., Caruso M., Caci G., Polosa R.: Lack of Substantial Post-Cessation Weight Increase in Electronic Cigarettes Users. Int J Environ Res Public Health 2018; 23,15(4).

24. Sari M.I., Sari N., Darlan D.M., Prasetya R.J.: Cigarette Smoking and Hyperglycaemia in Diabetic Patients. Open Access Maced J Med Sci 2018;15,6(4):634-7.

25. Schechter M.D., Cook P.G.: Nicotine-induced weight loss in rats without an effect on appetite. Eur J Pharmacol. 1976;38(1):63-9.

26. Singh H., Kennedy R.D., Lagasse L.P., Czaplicki L.M., Cohen J.E.: E-cigarettes and Weight Loss-Product Design Innovation Insights From Industry Patents. Nicotine Tob Res. 2018; 9,20(8):1010-4.

27. Teasdale J.E., Newby A.C., Timpson N.J., Munafò M.R., White S.J.: Cigarette smoke but not electronic cigarette aerosol activates a stress response in human coronary artery endothelial cells in culture. Drug Alcohol Depend. 2016; 01,163:256-60. 
28. Verhaegen A., Van Gaal L.: Do E-cigarettes induce weight changes and increase cardiometabolic risk? A signal for the future. Obes Rev. 2017;18(10):113646.
29. Zarobkiewicz M.K., Wawryk-Gawda E., Woźniakowski M.M., Stawiński M.A., Jodłowska-Jędrych B.: Tobacco smokers and electronic cigarettes users among Polish universities students. Rocz Panstw Zakl Hig 2016;67(1):75-80.

Received: 15.04 .2019

Accepted: 27.06.2019 